\title{
SEJARAH DAKWAH DI LEMBAH PALU
}

\section{Syamsuri Syamsuri}

email: syamsuri.akil@gmail.com

Dosen Tetap Pada Jurusan Komunikasi dan Penyiaran Islam IAIN Palu

\section{Abstract :}

There are three phases of the spread and development of Islam in Palu: mythological, ideological and scientific phases. In this paper, the figures of these three phases will be discussed. At this phase, the approach of Muslim scholars (ulama) is to show natural symbols in spreading and teaching Islam. Spiritual power becomes a key of the success of ulama. There are three ulama who play a role in a mythological phase, Abdullah Raqi "Datuk Karama", a son of Minangkabau coming to Palu in 1650. He was followed by Pue Imbatu "Syekh Lokiya", a native Muslim scholar, and then followed by Daeng Konda "Pue Bulangisi", a noble man who is popular with his teaching "karaeng". This teaching refers to a leading figure Syekh Yusuf Tuanta Salamaka Tajul Khalwati, a national hero of South Africa and Indonesia.

$$
\begin{aligned}
& \text { هناك ثلاث مراحل لانتشار و تطور الإسلام فى بالو؛ ميثولوجي و إيديولوجي وعلمي. وفى هذا }
\end{aligned}
$$

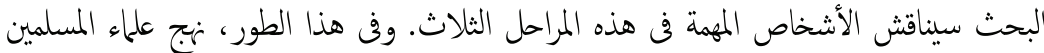

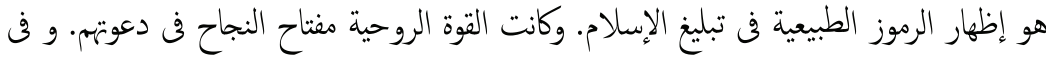

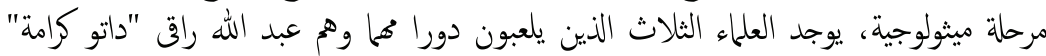

$$
\begin{aligned}
& \text { الذي جاء من مينانجكابوي إلى بالو في سنة . } 170 \text {. ثخ جاء فو إمباتو (Pue Imbatu) }
\end{aligned}
$$

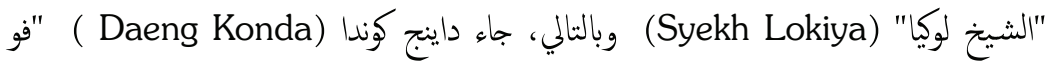

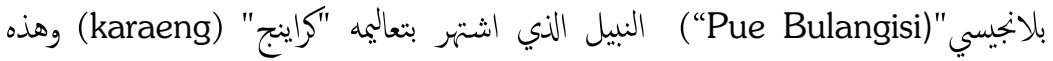

$$
\begin{aligned}
& \text { التعاليم تشير إلى العالم المشهور الشيخ يوسف تاج الخلوتي. }
\end{aligned}
$$

Kata Kunci : ulama, raja, dan umat. 
Syamsuri Syamsuri, Sejarah Dakwah di Lembah Palu

\section{A. Pendahuluam}

Islam datang di Lembah Palu tidak mungkin bisa dipisahkan dari jaringan global zaman itu. Islam menjadi penanda pada area koneksitas dengan dunia luar, bahwa Lembah Palu diakui keberadaannya dan memiliki kepentingan yang diperhitungkan sehingga menjadi agenda dakwah Islam. Masyarakat Lembah Palu memiliki bukti kepurbakalaan sebagai jejak peradaban masa lalu.

Berbagai penelitian menyebutkan situs megalitik di tiga lembah Lembah Besoa, Lembah Bada, dan Lembah Napu - diperkirakan sudah berusia ribuan tahun atau sejak 2000 - 2500 tahun Sebelum Masehi (SM), tepatnya pada permulaan zaman megalitik - masuknya zaman bercocok tanam. Keberadaan situs-situs ini adalah simbol masuknya manusia pertama ke Sulawesi Tengah, sekaligus awal peradaban di wilayah ini.

Tanwir La Maming, arkeolog Sulawesi Tengah yang cukup lama melakukan penelitian pada situs-situs di tiga lembah ini, mengatakan, di Indonesia bahkan di dunia, situs megalitik di tiga lembah ini punya keunikan dan cirri khas yang tidak dimiliki situs di tempat lain. Keunikan dan ciri khasnya antara lian setiap situs merupakan satu kesatuan yang melambangkan kepercayaan, rumpun etnis atau tempat tinggal, serta pola hidup masyarakat setempat pada masa itu. Misalnya, dalam satu situs ada tempat pemujaannya, tempat mandi, arca manusia sebagai simbol nenek moyang, alat bermain, kuburan, alat bercocok tanam, dan lainnya. Arah hadap mata angin arca-arca dalam setiap situs yang berbeda antara satu 


\section{$\Delta L-$ nis $H \exists \bar{\Delta}$ H, Vol. 11 No. 1, Januari-Juni 2015: 01-20}

situs dengan situs lainnya melambangkan adanya kepercayaan yang berbeda-beda pada setiap rumpun. ${ }^{1}$

Seiring dengan kondisi peradaban di tiga lembah ini, pergerakan manusia, setapak demi setapak, akhirnya mencapai wilayah pantai. Namun kiblat kehidupan masih mengarah ke arah lembah, menyebabkan keterampilan melaut belum dimiliki oleh penghuni lembah. Kedatangan orang Bugis dan Mandar menyebabkan terjadinya asimilasi antara manusia pengarung laut dengan manusia penghuni lembah.

Pada pembukaan Sail Tomini 19 September 2015 di Pantai Kayubura Kabupaten Parigi Moutong yang dihadiri Presiden Republik Indonesia Joko Widodo, ditampilkanlah tarian massal kolosal yang berkisah tentang asal mula penamaan Teluk Tomini. Hikayat datangnya pelaut dari Mandar yang disambut masyarakat setempat dengan teriakan, to mene, to mene, to mene. Bagi orang Bugis Mandar, dilafalkan "To Mini”.

Pada tahun 1650, datanglah Abdullah Raqi dan rombongan sebanyak 50 orang di Lembah Palu. Muballig ini diutus oleh Kerajaan Aceh sebagai "duta besar" untuk membawa pesan diplomatik kepada raja-raja di Lembah Palu. Tercatat Raja Kabonena Pue Njidi yang menerima seruan diplomatik seraya memeluk agama Islam.

Islam tampil membawa angin perubahan sosial, yakni tauhid (penyatuan) ideologi yang mempersatukan pandangan tentang ajaran keesaan Tuhan, yang sebelumnya di tampilkan dalam bentuk ritual yang berbeda-beda. Ada ajaran "dewata sewwae" di Sulawesi dan

${ }^{1}$ Reni Sri Ayu, "Situs Purbakala, Menjelajah Awal Peradaban Manusia di Sulawesi Tengah", Kompas, (Jakarta : PT Gramedia, 16 Agustus 2011), h. 39. 
Syamsuri Syamsuri, Sejarah Dakwah di Lembah Palu

“Manunggalin Kaula Gusti” di Jawa, yang ternyata memiliki kesamaan dengan ajaran Islam. Oleh karenanya, para muballig memiliki tugas untuk menyesuaikan ritual-ritual masyarakat setempat dengan ajaran Islam.

Nasaruddin Umar, melukiskan hal itu dengan "Proto Indonesia", sebagai berikut :

"Cikal bakal Indonesia terbentuk bukan baru pada abad modern ketika kolonialisme meninggalkan tanah air. Bukan pula ketika Indonesia mulai bersentuhan dengan agama Hindu yang berasal dari anak benua India atau agama Islam yang berasal dari Timur Tengah. Jauh sebelumnya sudah ada cikal bakal Indonesia. Bahkan Indonesia juga mengenal prasejarah yang ikut membentuk terwujudnya kondisi obyektif bangsa ini.

Bukti-bukti arkeologis dan antropologis menunjukkan adanya aktivitas manusia prasejarah di kawasan ini. Ditemukannya beberapa fosil manusia purba, seperti Meganthropus Paleojavanicus (Sangiran), Pithecanthropus Robustus (Trinil), Pithecantropus Erectus (Homo Erectus), Pithecanthropus Dubius (Jetis), Pithecanthropus Mojokertensis (Perning), Homo Javanesis (Sambung Macan), Homo Soloensis (Ngandong), Homo Sapies Archaic, Homo Sapies Neandertahlman, Homo Sapiens Wajakensis (Tulungagung), dan Homo Modernman.

Analisis kehidupan manusia purba Indonesia menunjukkan adanya aktivitas budaya dan peradaban, sehingga sulit untuk mengatakan bahwa agama Hindu dan Islam yang begitu banyak member bekas di dalam seni, budaya, dan peradaban nusantara, seolah-olah memasuki ruang yang hampa budaya sehingga merekalah yang mengisi kekosongan itu. Bukti laian menunjukkan sistem religi sudah dikenal di kawasan ini. Bahkan sejumlah daerah sudah sejak lama mengenal konsep Dewata Sewwae. Itulah sebabnya Islam begitu mudah diterima sebagai agama mayoritas di Tanah Air karena sudah menemukan pangkalan pendaratannya. Para raja serta-merta memeluk agama Islam karena dianggapnya bagian dari kelanjutan dari sistem religi mereka.

Proto Indonesia, yaitu periode adi antara pasca-prasejarah dan sejarah modern Indonesia menarik untuk dikaji lebih mendalam karena periode ini merupakan peletakan dasar esensial masyarakat nusantara awal yang kemudian membentuk dasar kebudayaan dan peradaban nusantara yang kemudian menjadi 
Indonesia. Walaupun periode ini belum ditemukan banyak bukti sejarah dalam bentuk tertulis namun laporan-laporan akademik dari luar negeri sudah banyak mngungkap suasana proto Indonesia, seperti yang diungkap oleh Ptolemaus yang menggambarkan adanya kepulauan yang disebut Khersonesos (Yunani : Pulau Emas) dan sejarah China yang disebutnya dengan Ye-po-ti yang diantaranya diperkenalkan dengan Jabadiou/Jawa. Di zaman ini sudah dikenal wilayah Jawadwipa, Swarnadwipa, Bugis, dan lain-lain.

Analisis sistem budaya juga menggambarkan masa ini sebagai masa akulturasi yang amat penting, di mana budaya dan sistem religi luar bisa beradaptasi dalam konteks budaya kepulauan nusantara. Di dalamnya ada pengaruh Hindu, Arab (Islam), China, Portugis, dan Inggris. Sistem budaya, sistem religi, sistem ekonomi, dan sistem teknologi sudah banyak ditemukan di pusatpusat kerajaan pada waktu itu.

Jika kita berbicara dengan karakter bangsa, kebudayaan nasional, atau nilai-nilai luhur budaya bangsa, bukan berarti kita berbicara dengan nilai-nilai luar, sperti Hindu, Islam, dan budaya Barat yang diperkenalkan oleh saudagar Barat yang berikut menjadi colonial, yang begitu banyak member warna di dalam peradaban kita. Karakter dan watak dasar bangsa kitatetap eksis di tengah kemajemukan nilai. Hindu dan Islam berhasil menancapkan pengaruhnya tetapi sebelumnya nilai-nilai itu terlebih dahulu mengalami proses pengindonesiaan. ${ }^{2}$

Ajaran Islam yang masuk dan berkembang di Lembah Palu, sesuai dengan Proto Indonesia, yang tidak mengalami resistensi. Para bangsawan dan rakyatnya menerima Islam dengan sembari sebagai alat pemersatu di antara kelompok-kelompok masyarakat lainnya. Para pembawa Islam (da'i) memberi penghormatan kepada raja-raja yang ditemui di Nusantara. Bukti penghormatan itu berupa pemberian gelar "sultan", yang menandai adanya legitimasi kerajaan di bawah Daulah Khilafah Turki Usmani.

${ }^{2}$ Nasaruddin Umar, "Proto Indonesia", Jurnal Nasional, (Jakarta: PT Nusa Pradana, 16 Desember, 2011), h. 1. 
Syamsuri Syamsuri, Sejarah Dakwah di Lembah Palu

Para pembawa Islam tidak merebut simpati rakyat untuk merebut kekuasaan, sehingga para raja menganggap bahwa Islam bukan ideologi ancaman. Justru yang terjadi, para raja merasa terbantu dengan kehadiran muballig, karena mampu member efek ketudukkan rakyat dalam masalah tauhid yang berimplikasi pada penguatan posisi raja. Semboyan yang digalakkan oleh muballig adalah raja sebagai khalifatullāh fi al-ardh. Raja sebagai wakil Tuhan di bumi memberikan legitimasi doktrinal terhadap eksistensi raja.

Melihat peluang keberterimaan Islam di Nusantara, tidak sedikit raja yang ikut membantu usaha penyebaran agama Islam. Di Lembah Palu, terdapat beberapa raja yang mendukung dan membantu penyebaran dan pengembangan agama Islam, antara lain, Raja Kabonene Pue Njidi pada tahun 1650, Raja Palu Pue Nggari, Raja Bangga Pue Bongo, hingga Raja Palu bernama Djanggola yang menerima kedatangan Sayyid Idrus bin Salim Aldjufri pada tahun 1930.

\section{B. Tokoh-Tokoh Ulama Pembawa dan Penganjur Agama Islam di Lembah Palu}

\section{Datokarama}

Abdullah Raqi alias Datuk Karama adalah ulama besar dari Minangkabau, ia hidup semasa dengan Datuk Bakajabian dan Datuk Bakopiame. Datuk Karama lahir di Sumatera Barat Pesisir Selatan, berusia sekitar 98 tahun ketika wafat di Lembah Palu tahun 1709. Di usia 22 tahun, Abdullah Raqi dibawa ayahnya ke Mekkah, untuk menimba ilmu pengetahuan. Abdullah Raqi adalah seorang ulama yang rendah hati, teguh dalam pendirian dan hatinya lembut, walaupun beliau menguasai banyak bidang ilmu. Ia berpegang teguh pada Mazhab Syafi'i 


\section{$\Delta L-n i s h \exists \bar{\lambda} H$, Vol. 11 No. 1, Januari-Juni 2015: 01-20}

dalam fiqih dan penganut Ahlussunnah wal Jamaah mengikuti ajaran Mazhab Imam Abu Hasan al-Asy'ari dan Imam Abu Mansur al-Maturidi dalam akidah. Abdullah Raqi adalah murid dari Syekh Abdurrauf Aceh. ${ }^{3}$

Abdullah Raqi juga dikenal sebagai ulama yang sangat peduli terhadap pencerdasan umat. Beliau menguasai ilmu fiqih, sejarah, tarekat/tasawuf, ilmu hitung dan geometri. Abdullah Raqi dapat memprediksi dan menentukan arah kiblat, serta berfungsi untuk mengetahui rotasi bumi dan membuat kompas yang berguna saat berlayar. Selama belajar di tanah suci, Datuk Karama menempuh pelajaran intensif tentang ilmu tarekat serta memasuki suluk ${ }^{4}$ di Jabal Abu Qubaisy. Pendalaman intensif tersebut, Abdullah Raqi dikukuhkan sebagai ahli tarekat yang memperoleh ijazah dari Tarekat Naqsyabandiyah.

Pada tahun 1637, Abdullah Raqi kembali ke tanah air. Ia memilih mengamalkan ilmunya secara langsung kepada masyarakat; mengajarkan ilmu tauhid dan ilmu Alqurān. Penyampaian dakwah Abdullah Raqi ditempuh secara privat tanpa menggunakan sistem kelembagaan dan organisasi pendidikan. Kiprah dakwahnya itulah yang memberi warna baru di bidang kegiatan keagamaan di Sumatera Barat. ${ }^{5}$

Pada tahun 1639, Abdullah Raqi diundang oleh Sultan Iskandar Nuda Aceh, untuk bermusyawarah tentang penyebaran dan perkembangan Islam di Pulau Sulawesi yang dihadiri utusan Sultan

${ }^{3}$ Moh. Ali, Datuk Karama dan Islamisasi Masyarakat Kaili di Lembah Palu, (Cirebon : CV. Perwira, 2014), h. 47.

${ }^{4}$ Suluk ini kemudian dilanjutkan oleh ulama periode berikutnya yaitu Syekh Lokiya.

${ }^{5}$ Ibid., h 48. 
Syamsuri Syamsuri, Sejarah Dakwah di Lembah Palu

Babullah Ternate. Pada rapat itu, disepakati Abdullah Raqi berdakwah di Pulau Sulawesi, dan akan berkoordinasi dengan Kerajaan Ternate untuk melakukan pemetaan dakwah di wilayah tersebut. Adapun waktu keberangkatan untuk menyebarkan Islam di Pulau Sulawesi diserahkan sepenuhnya kepada Abdullah Raqi. ${ }^{6}$

Perjalanan panjang nan jauh yang ditempuh Abdullah Raqi bersama rombongan 50 orang dari Sumatra Barat menuju Lembah Palu Sulawesi Tengah pada tahun 1650, tentu mengalami petualangan berat di Samudra Hindia dengan tantangan laut yang diterpa ombak dan tiupan angin. Kapal yang menjadi alat transportasi tentu dengan kondisi yang sangat memadai, karena setelah mendarat di Lembah Palu tidak ada lagi pelabuhan berikutnya yang dituju. Artinya, kapal itu terakhir dipakai oleh Abdullah Raqi dan rombongan ketika berlabuh di Lembah Palu.

\section{Syekh Lokiya}

Nama "Syekh Lokiya" merupakan pengembangan dialek masyarakat Lembah Palu dalam memandang tokoh penganjur agama Islam di abad ke 17 ini. "Sebutan nama sebenarnya orang tua itu pada awalnya adalah sulukiyah. Karena beliau mengajarkan tarekat sulukiyah. Namun nama itu disebut oleh masyarakat secara berantai dari seseorang ke orang lain, dari kampung ke kampung, hingga dari generasi ke generasi, sehingga dari sulukiyah berubah menjadi Syekh Lokiya".

Syekh Lokiya tampil sebagai generasi kedua dalam penyiaran Islam di Lembah Palu. Pengembangan dakwah pada tahap kedua selalu

${ }^{6}$ Ibid., h. 49.

${ }^{7}$ Ibrahim Latepo, warga Desa Towale, wawancara, 7 September 2015. 


\section{$\Delta L-$ nis $H \exists \bar{\Delta}$ H, Vol. 11 No. 1, Januari-Juni 2015: 01-20}

mengajarkan ilmu Alqurān, karena dipandang sebagai hal yang mendasar dalam pengetahuan tentang ajaran Islam. Dari pengetahuan berimplikasi pada pengamalan ajaran Islam. Hal ini terlihat ketika Nabi Muhammad turun dari Goa Hira, selesai menerima wahyu pertama disusul kedua dan ketiga di Mekkah. Qum Fa anzir, (berdiri lalu sampaikan), Nabi Muhammad kemudian menjadikan rumah Arqam bin Abi Arqam sebagai pusat pendidikan Islam (Islamic Centre). Di rumah itu, Nabi Muhammad menyampaikan ajaran secara diam-diam kepada orang-orang Mekkah.

Seperti di Makassar, setelah Islam disampaikan oleh Datuk Ri Bandang, Datuk Patimang, dan Datuk Ri Tiro, lalu tampillah Syekh Yusuf menjadi guru mengaji. Masyarakat lokal yang cepat menerima ajaran Islam selanjutnya langsung mengajarkannya. Kemampuan pembawa Islam memberdayakan masyarakat setempat untuk menerima estafet dakwah, menunjukkan cara dakwah yang berkesinambungan. Niat suci memang tampak dalam kegiatan dakwah pada masa-masa permulaan penyiaran Islam.

Ada dua ajaran pokok Syekh Lokiya yaitu, guru mengaji dan tarekat Sulukiyah.

\section{a. Guru Mengaji}

Keadaan pendidikan Alqurān pada fase permulaan Islam di Nusantara yang sudag barang tentu ternasuk Lembah Palu, dikemukakan oleh Deliar Noer, sebagai berikut :

Bagaimanakan pendidikan dasar dalam agama (Islam) di Indonesia ketika itu ? Ini mula sekali diberikan dalam lingkungan keluarga atau family ketika si anak berumur kira-kjira empat atau lima tahun. Maksud pengajaran ini terutama ialah untuk membaca Alquran. Sering pula si anak mengunjungi gurunya yang mempergunakan rumahnya 
Syamsuri Syamsuri, Sejarah Dakwah di Lembah Palu

(rumah guru) sebagai tempat mengaji atau mempergunakan lamggar di kampong yang bersangkutan sebagai sekolah.

Dalam tingkat ini mempelajari Alqurān hanyalah dimaksudkan untuk dapat membaca atau mengulang-ulangnya. Tiada dirasakan keperluan untuk dapat membaca atau mengulang-ulangnya. Tiada dirasakan keperluan untuk memahami isinya. Pelajaran pun tidaklah diberikan dalam kelas yang teratur baik; sebaliknya sang guru, bergantiganti menhdapai muridnya secara perseorangan di tengah riuh rendahnya suara anak-anak lain mengulang bacaan mereka. Dengan demikian maka kemajuan si murid semata-mata bergantung pada ketekunan dan kecakapannya sendiri.

Dalam tingkat permulaan di samping mempelajari membaca Alquran, urid-murid juga diajarkan cara bersembhyang (shalat). Dalam rangka belajar shalat ini, walaupun si murid belum lagi dapat menghafal seluruhnya segala bacaan shalat, ia dilatih untuk ikut pada shalat berjamaah agar terbiasa melakukan kewajiban ini.

Di sampimg itu beberapa masalah teologi (ketuhanan) juga dipelajari, yang pada garis bersarnya berpusat pada sifat dua puluh. Hal ini bersangkut dengan soal iman (kepada Allah), dengan keesaan Tuhan atau tauhid serta dengan maksud menjauhkan syirik, suatu dosa yang dianggap tidak terampunkan.

Pelajaran elementer tersebut biasanya diberikan pada waktu petang atau malam hari. Biasanya anak-anak di kampong atau di desa membantu orang tua mereka pada pagi dan siang hari, baik di sawah, kebun atau lading, sedangkan guru-guru (mengaji) juga harus mencari nafkahnya di waktu pagi dan siang hari, yaitu dengan mengerjakan pekerjaan yang yang biasa dilakukan oleh orang-orang di kampong, 


\section{$\Delta L-n i s H \exists \bar{d} H$, Vol. 11 No. 1, Januari-Juni 2015: 01-20}

termasuk di antaranya bekerja di sawah. Sebenarnya pelajaran dan latihan beragama itu mendapat dukungan dari orang tua dan guru, bahkan dari masyarakat kampung atau desa itu. ${ }^{8}$

Pembelajaran Alqurān menjadi dasar pengetahuan tentang ajaran Islam. Metode pengajaran Alqurān di Lembah Palu sangat dipengaruhi oleh metode orang Bugis, sehingga cara penyebutannya menggunakan bahasa Bugis. "Alefü" dikenal di Tanah Kaili sebagai pintu masuk untuk membaca Alqurān. Alefu yang dimaksud adalah Qāidah Baghdadiyah (Metode Baghdadiyah).

\section{b. Tarekat Sulukiyah}

Gerakan tarekat ini menempuh jalur suluk. Ditinjau dari asal usul bahasanya, suluk berasal dari kata dalam bahasa Arab, yaitu sulukun yang merupakan isim masdar dari salaka artinya, melalui atau menempuh jalan. Kemungkinan suluk berasal dari perkataan sulukun, merupakan isim jama' dari silkun, berarti benang atau tali yang digunakan untuk merangkai intan atau permata. ${ }^{9}$

Pengertian di atas yang berkaitan dengan arti kata suluk, yaitu menempuh jalan, dapat dihubungkan dengan ajaran tasawuf, yaitu berarti jalan yang harus dilalui untuk menuju kesempurnaan batin. ${ }^{10}$ Sedangkan arti suluk yang berarti benang atau tali, mempunyai makna atau pengertian bahwa suluk dipakai sebagai petunjuk yang menjadi tali pengikat atau penghubung antara makhluk dengan khaliknya atau bisa

8 Deliar Noer, Gerakan Modern Islam di Indonesia 1900 - 1942, (Jakarta : LP3ES, 1996), h. 14-15.

${ }^{9}$ Louis Ma'luf, Al-Munjid, (Beirut: Dar al-Masyriq, 1975), h. . 347.

${ }^{10}$ Aboebakar Atjeh, Pengantar Ilmu Tarekat (Solo: CV. Ramadhani, 1985), h. 121. 
Syamsuri Syamsuri, Sejarah Dakwah di Lembah Palu

jadi merupakan petunjuk tentang jalan yang harus ditempuh oleh seseorang untuk sampai pada makrifat Tuhan. ${ }^{11}$

Hal ini sebagaimana disebutkan dalam Q.S. an-Nahl (16) : 69;

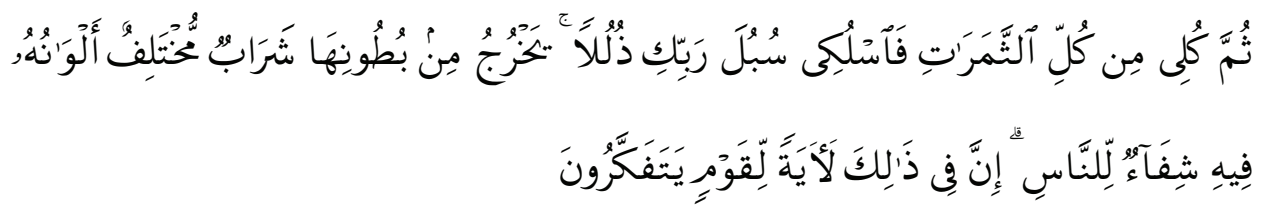

Terjemahnya :

“...Tempuhlah jalan Tuhanmu yang dimudahkan bagimu....". 12

Beberapa ahli tasawuf memberi tafsiran lain terhadap ayat di atas. Di antaranya ada yang memberi arti "maka bersuluklah kamu...", dan menjadikannya sebagai salah satu dasar bagi ajaran tasawuf. ${ }^{13}$ Kemudian hakikat suluk itu sendiri dalam ilmu tasawuf adalah mengosongkan diri dari sifat mazmumah (buruk) yaitu dari maksiat lahir dan batin, dan mengisinya dengan sifat-sifat yang mahmudah (terpuji). Dalam bersuluk disyariatkan untuk melakukan sebuah perjalanan spiritual yang panjang dengan berbagai maqamnya, yang akhirnya akan memperoleh tujuan yang dikehendaki, yakni kesempurnaan iman. ${ }^{14}$

${ }^{11}$ Sindu Galba, Sri Mintosih, dkk., Suluk Sujinah, (Jakarta: Departemen Pendidikan dan Kebudayaan Direktorat Jenderal Kebudayaan Proyek Penelitian dan Pengkajian Kebudayaan Nusantara, 1992), h. 3.

${ }^{12}$ Departemen Agama RI, Alqurān dan Terjemahnya, h. 257

${ }^{13}$ Musthafa Zuhri, Kunci Memahami Tasawuf, (Surabaya: PT Bina Ilmu, 1979), h.160.

${ }^{14}$ Asywadie Syukur, Ilmu Tasawuf I, (Surabaya: PT.Bina Ilmu, 1982), h. 59. 


\section{$\Delta L-n i s h \exists \bar{\lambda} H$, Vol. 11 No. 1, Januari-Juni 2015: 01-20}

Jalan kepada Allah itu banyak, sama dengan banyaknya jiwa makhluk. Adapun jalan yang paling dekat ada tiga bagian ${ }^{15}$ :

1. Jalan al-akhyār, yaritu dengan banyak melakukan shalat, puasa membaca Alqurān, hadis, jihad dan lain-lain dari amal lahiriah. Salik yang sampai kepada Allah dengan jalan ini sedikit dari yang sedikit.

2. Jalan aṣab al-mujahid al-ṣaqa dengan latihan berat untuk mengganti akhlak yang buruk, membersihkan jiwa dan mensucikan hati. Yang sampai dengan jalan ini lebih banyak dari yang pertama. Pada yang pertama yang dilihat hanya amal lahir, tanpa yang batin. Yang kedua lebih memperhatikan batin daripada lahirnya.

3. Jalan ahli zikir, yang cinta kepada Allah lahir dan batin. Yang sampai ahli bidaya, lebih banyak ahli nihaya. Mereka ini memperhatikan amal lahir dan batin semuanya.

Adapun pokok-pokok dari jalan ini ada sepuluh :

1. Tobat kepada Allah dari segala dosa, lahir dan batin.

2. Zuhud di dunia

3. Tawakkal kepada Allah

4. Puas dengan apa yang diberikan Allah keadanya (qanaah)

5. Menjauhkan diri dari makhluk dengan tidak condong hatinya kepada mereka

6. Benar-benar tawajuh kepada Allah

7. Sabar menghadapi malapetaka

${ }^{15}$ Tujimah, Syekh Yusuf Makassar Riwayat dan Ajarannya, (Jakarta : UI Press, 1997), h. 59. 
Syamsuri Syamsuri, Sejarah Dakwah di Lembah Palu

8. Rela kepada kada dan kadar, menyerahkan semua perkara kepadaNya

9. Terus menerus zikir lahir dan batin, tidak alpa kepada Allah

10. Benar-benar mendekati Allah ${ }^{16}$, seperti bunyi hadis :

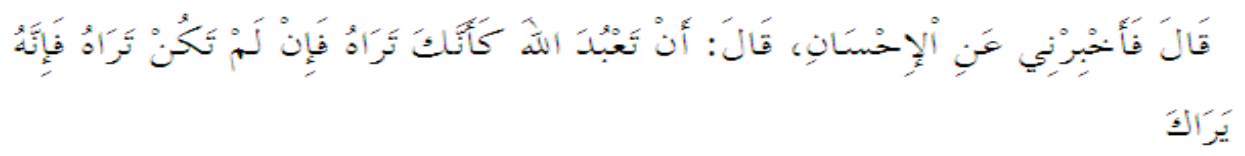

Artinya :

Suatu ketika Malaikat Jibril mendatangi Nabi Muhammad lalu bertanya tentang ihsan. Nabi Muhammad menjalaskan bahwa ihsan adalah engkau menyembah Allah seperti engkau melihatNya. Jika engkau tidak mampu melihatNya, maka sesungguhnya Dia melihat kamu (beribadah). ${ }^{17}$

Kemudian syarat zikir menurut ahli Fana ada 10 langkah untuk sampai kepada maksud mendapat pertolongan Allah, yaitu :

1. Cari tempat yang sepi, tidak terdengar seorang pun.

2. Pakaian zahir suci, badan zahir dan batin suci, dengan wudhu.

3. Melepaskan asap wangi untuk memudahkan pada waktu zikir.

4. Duduk bersila waktu zikir.

5. Menghadap kiblat

6. Meletakkan kedua tangan di atas kedua paha, kemudian mengangkat jeriji telunjuk waktu nafi dan meletakkannya pada waktu ithbat.

7. Ikhlas dalam niat hanya karena Allah.

8. Mendatangkan arti yang hakiki dalam sirr (rahasia).

${ }^{16}$ Ibid., h. 59.

${ }^{17}$ Abul Husain Muslim bin al-Hajjaj al-Qusyairi an-Naisaburi, Sahih Muslim, Hadis Nomor 8. 
9. Berzikir dengan kemauan, hormat, dan takzim.

10. Tawajuh dengan sempurna terhadap Allah dengan menyisihkan selain Dia dari perasaan, menyisihkan diri sendiri kemudian yang berzikir dan zikirnya menjadi yang diingat sendiri, karena fana fillāh. ${ }^{18}$

Kesepuluh langkah itu disebut tirakat, yang menuntun peserta tarekat untuk konsentrasi dalam pikiran, sehingga potensi zikir yang terdapat jiwa, sedikit demi sedikit terpancar dalam kesaktian dan keharuman pribadi yang sudah sampai pada tingkat tajalli. Masyarakat muslim sangat menggandrungi aspek ritual ini karena dianggap sebagai buah (halawah) dari pekerjaan beribadah selama hidupnya.

\section{Daeng Konda}

Daeng Konda yang dikenal juga dengan nama Pue Bulangisi adalah bangsawan Sendana Mandar yang datang di Lembah Palu khususnya di Tawaeli untuk mengajarkan agama Islam. Kerajaan Sendana, adalah salah satu kerajaan yang termasuk dalam kelompok kerajaan Pitu Babana Binanga, artinya tujuh kelompok kerajaan yang terdapat di pesisir dan membentuk kesepakatan sebagai suatu entitas yang bernama Mandar. Kerajaan ini berposisi sebagai ibu dalam kelompok Babana Binanga mendampingi posisi kerajaan Balanipa sebagai bapak. ${ }^{19}$

\footnotetext{
${ }^{18}$ Tujimah, Syekh Yusuf..., h. 59.
}

${ }^{19}$ Kemiripan dengan sistem kerajaan di Tanah Kaili yang disebut Pitunggota, ada tujuh kerajaan yang memiliki kekuasaan terbentuknya sebuah kerajaan induk. Pitunggota, yang terkenal yaitu Kerajaan Sigi meliputi : Dolo, Rarantika, Wonggo, Kulawi, Sibalaya, Sidondo, Pakuli 
Syamsuri Syamsuri, Sejarah Dakwah di Lembah Palu

Adapun wilayah negeri Pitu Ulunna Salu', terdiri atas: Tabulahan, Aralle, Mambi, Bambang, Rantepulahan atau Rantebulawan, Matanga, Tabang atau Tandong, Tu'bi. Pada mulanya, pemimpin Tabulahan adalah Tumakaka bernama Indo-Lita'. Adapun negeri-negeri dalam kawasan Pitu Ba'bana Binanga ialah: Balanipa, Sendana, Banggae, Pamboang, Tappalang, Mamuju, Binuang.

Pada awalnya Sendana ditemukan oleh seorang Tomakaka Tabulahan di Ulu Salu bernama Daeng Tumana, yang mendirikan perkampungan di wilayah Buttu Suso, daratan di puncak gunung Sendana. Tak lama setelah itu adik kandung Daeng Tumana yang bernama Daeng Palulung bersama istrinya Tomesaraung Bulawang menyusul ke daerah Buttu Suso dan mendirikan satu kerajaan yang diberi nama Sendana, yang asal kata penamaannya berasal dari sebatang tongkat kayu Cendana yang dimiliki oleh Tomesaraung Bulawang yang ditancapkan di puncak Buttu Suso.

Sebagaimana diketahui bahwa penyebaran Islam dari Kerajaan Gowa sampai di Kerajaan Balanipa Mandar pada tahun 1610. Dari Mandar menyebar agama Islam ke Tanah Kaili, yang nyatanya adalah Daeng Konda yang merupakan bangsawan Kerajaan Mandar. Kedekatan Mandar dengan Kaili, diabadikan pada lirik lagu "Bura' Sendana" ciptaan H.A. Syaiful Sinrang, sebagai berikut :

\section{Bura' Sendana (Bunga Cendana)}

bura' sendana (Bunga Cendana)

lilion naun di kaeli (Terdampar di Kaili)

poleo naun (Datang nun di sana)

ko'bi-ko'bianda kaka'u (Tolong kasi tau kakandaku) 
damo nadiong (Jangan tinggal di sana)

masae mattoro' lawuang (terlalu lama)

kembang matau (bengkak Mataku)

mepatto sau di lawuang (tatkala memandang laut)

jappo mi dini (Sedih sekali disini)

pasangan passinding dhadha' $u$ (sesak pilu didada)

najappo-jappo (sedih-sedih di air mata)

uwai lolong di mata'u (yang selalu berlinang dipipi)

bulan diaya (Bulan purnama dilangit)

meapa ami i kacici (bagaimana berita adindaku)

tumette ami (apa masih merajut kain tenun)

tumette jalepe bulawang (merajut benang emas)

inai natannungan (siapa direnungkan)

ana'na karaeng di tallo (anaknya Raja di Tallo)

pitu panona (ada tujuh pintu bunga)

mogeter-geter di dhadhanna (berjejer didadaku)

$u$ ala mesa (Diambil satu)

u paccobo'boang naiwaine (untuk disimpan dikepala sang gadis)

diang la'binna (ada lebihnya)

u pacco'boang tomawuweng (disimpan dikepala orang tuanya)

Pada event internasional yang diselenggarakan Pemerintah Provinsi Sulawesi Tengah, Sail Tomini, 19 September 2015, dibuka oleh Presiden Republik Indonesia, Joko Widodo, ditampilkan tarian kolosal yang mengisahkan lelaki Mandar turun dari perahu sandeq lalu dijemput oleh perempuan Kaili, kemudian menjadi ikatan suami istri. Perahu 
Syamsuri Syamsuri, Sejarah Dakwah di Lembah Palu

Sandeq dari Mandar kemudian menjadi ikon utama dalam even Sail Tomini.

Perahu sandeq adalah perahu tradisional suku Mandar. Suku Mandar ini mendiami pulau Sulawesi bagian barat. Suku Mandar dikenal sebagai suku yang hidup dominan di wilayah maritim atau laut. Tak heran, banyak kalangan menilai bahwa mandar adalah pelaut ulung yang melintasi luasnya lautan dengan keberaniannya menggunakan perahu sandeq.

Penamaan sandeq berasal dari bahasa mandar yang sama "sande" yang berarti runcing, sebagaimana bentuk perahu tersebut yang memang nampak runcing di bagian haluan dan buritannya. Haluan dan buritan ini masing-masing disebut sebagai paccong, paccong uluang untuk haluan dan paccong palaming untuk buritan.

Pada perjalanan penyebaran Islam, Daeng Konda melanjutkan Ajaran Syekh Yusuf. Syekh Yusuf adalah penerima ijazah sebagai mursyid Tarekat Khalwatiyah. Penerimaan gerakan tarekat ini di Lembah Palu secara aplikatif disenandung dengan nama ajaran Syekh Yusuf. Sufi asal Makassar ini menjadi legenda bagi orang Makassar, Bugis, dan Mandar sehingga dengan otomatis, kehadiran orang-orang itu di Lembah Palu terjalin pula keakraban bagi pengikut Syekh Yusuf dari asal kampong mereka.

Daeng Konda atau disebut juga Pue Bulangisi tampil sebagai tokoh yang mampu menjadi magnet bagi orang Makassar, Bugis, dan Mandar untuk mengaktifkan pengajian tarekat Khalwatiyah. Orang Kaili yang memandang ajaran itu bukan dengan nama ajaran Syekh Yusuf tapi dengan sebutan "karaeng". Nama karaeng memang menjadi sapaan 


\section{$\Delta L-n i s h \exists \bar{\lambda} H$, Vol. 11 No. 1, Januari-Juni 2015: 01-20}

kehormatan bagi kasta tertinggi di suku Makassar. Sehubungan Syekh Yusuf adalah orang Makassar, lalu ajarannya itu disebut karaeng.

Ajaran Syekh Yusuf mendapat tempat di Lembah Palu karena dominan diamalkan oleh "orang selatan", karena mampu memberi pencerahan spiritual dalam menghadapi fluktuasi hidup pada waktu itu. Begitu pula, ada sebagian umat Islam ingin menyempurnakan keislaman mereka dengan cara beribadah secara khusus yang berbeda dengan masyarakat Islam lainnya.

\section{Penutup}

Keberterimaan Islam di Lembah Palu didukung oleh pandangan hidup ketuhanan Orang Kaili tentang Tuvu. Tuvu dapat bermakna Tuhan Sang Pencipta dan Tuvu juga bermakna hidup. Peninggalan megalit di Lembah Besoa dan Lembah Bada yang merupakan asal usul manusia Kaili, merupakan bagian dari proto Indonesia tentang hubungan manusia dengan Sang Pencipta.

Konsep alam, dalam pandangan kosmologi, bagi ulama adalah ma siwa ala llahi (tidak ada sesuatu yang menyamai Allah). Ulama memandang bahwa alam adalah bukan hanya sesuatu yang dapat disaksikan atau dialami secara empiris (ash-shahādah) akan tetapi juga sesuatu di luar jangkauan akal manusia. Ulama memasukkan alam seperti ini dalam kategori al-sam'iyāt, sesuatu yang dikenal semata-mata berdasarkan apa yang didengar (dibaca) dari al-Kitab (Alqurān) dan alSunnah. Mengenai alam yang bersifat al-sam'iyāt ini lebih banyak digambarkan secara ijmal (diperkenalkan secara umum) tanpa terinci. 
Syamsuri Syamsuri, Sejarah Dakwah di Lembah Palu

\section{Daftar Pustaka}

Aboebakar Atjeh, Pengantar Ilmu Tarekat, Solo: CV. Ramadhani, 1985.

Abul Husain Muslim bin al-Hajjaj al-Qusyairi an-Naisaburi, Sahih Muslim, Beirut: Dar al-Fikr, 1999.

Asywadie Syukur, Ilmu Tasawuf I, Surabaya: PT.Bina Ilmu, 1982.

Deliar Noer, Gerakan Modern Islam di Indonesia 1900 - 1942, Jakarta: LP3ES, 1996.

Louis Ma'luf, Al-Munjid, Beirut: Dar al-Masyriq, 1975.

Moh. Ali, Datuk Karama dan Islamisasi Masyarakat Kaili di Lembah Palu, Cirebon: CV. Perwira, 2014.

Musthafa Zuhri, Kunci Memahami Tasawuf, Surabaya: PT Bina Ilmu, 1979.

Nasaruddin Umar, "Proto Indonesia", Jurnal Nasional, Jakarta: PT Nusa Pradana, 16 Desember 2011.

Reni Sri Ayu, "Situs Purbakala, Menjelajah Awal Peradaban Manusia di Sulawesi Tengah", Kompas, (Jakarta: PT Gramedia, 16 Agustus 2011.

Sindu Galba, Sri Mintosih, dkk., Suluk Sujinah, (Jakarta: Departemen Pendidikan dan Kebudayaan Direktorat Jenderal Kebudayaan Proyek Penelitian dan Pengkajian Kebudayaan Nusantara, 1992.

Tujimah, Syekh Yusuf Makassar Riwayat dan Ajarannya, Jakarta: UI Press, 1997. 